\title{
The communicative dynamics and its relation with the social dynamics. Reflections for communication research from the paradigm of critical epistemology
}

\author{
Vivian Romeu \\ UNAM, Faculty of Political and Social Sciences, Communication Department, Mexico City \\ vromeu.romeu@gmail.com
}

\begin{abstract}
In this work the communicative phenomenon is understood as the germ of social action. This invites us to think of communication as expressive behavior through which the social, even the historical, is configured. Consequently, to think of communication in the social as social action demands to conceive and study the social reality as a reality in constant movement, that is, giving in the given. From the critique of the traditional concept of communication, through the epistemological legacy of Hugo Zemelman, this paper proposes a reflection on the role of communication in the shaping movement of social reality.
\end{abstract}

Keywords. social reality, communication, social action, social meanings, critical epistemologhy

\section{Introduction}

This text aims to elaborate a reflection on the way in which communication participates predominantly in the constitution of social reality. This avoids those theoretical approaches - specifically those that come from interactionist sociology ${ }^{1}$ - that postulate communication in the opposite direction, that is: as a consequence or result of social relations and not as the engine of them, which is what is here defend ${ }^{2}$.

For this we start from the paradigm of critical epistemology, raised by Hugo Zemelman since the second half of the twentieth century, and whose dialectical imprint allows us to apply for communicative processes as constitutive processes of the intrinsic movement of social reality. In that sense, what is sought here is to generate a reflection on the role of communication research in the nucleus of scientific inquiry of the social sciences. Therefore, the question that guides the reflections to be developed in this text can be

\footnotetext{
${ }^{1}$ Authors such as Herbert Blumer, George Herbert Mead, Erving Goffman, Gregory Bateson, Don Jackson, Ray Birdwhistell, Albert Scheflen and Paul Watzlawick (Winkin, 2008), encrypt communication positions that echo the legacy of Social Psychology and Symbolic Interactionism. From them, communication is conceived as a regulatory system of social relations and therefore as a mechanism that generates and sustains them. In fact, the meanings to which appeals from these positions are sociocultural meanings, that is, meanings inscribed within the positions of the subjects in the social structure, from which it follows that the construction of meanings depends on that position.

${ }^{2}$ In addition to the interactionist positions with which we share this premise, Luhmannian theory does respond directly to them, only that for Luhmann the communication configures a mechanism of social structuring, but without subjects. For the German sociologist, communication is the flow and interaction of information or differences, in the manner of an invisible and functional network that makes society possible, losing sight of the phenomenon itself, that is, the experiential wealth that emerges from the properly communicative and its role in the construction of the historically possible social, that is, of the life we live daily. For more information the consultation of Theory of society and pedagogy is recommended. Barcelona: Paidós, 1996, work of the author.
} 
formulated as follows: in what way are communicative processes configured as foundational processes of the socio-historical reality of the present, and how could this impact on scientific research of the comunication?

To answer the previous question, in a first section we focus on developing the way in which we understand communication and how it pays for its definition as a basis in the constitution of social reality. In the second section of this text we synthetically develop the main postulates of critical or Latin American epistemology, as it is also called, in order to lay the epistemological bases from which to articulate the foregoing. Finally, in the third section, we will focus on reflecting how this impacts communication research, placing special emphasis on the way in which communicative dynamics allows the creation of analysis niches for the understanding of the social.

\section{The communicative processes as founding processes of the social-historical in the present}

History, says Bloch $(2004)^{3}$, is not the facts of the past, but what is being configured in the present. That is why, for the author, history constitutes the social reality of the present where it is given as potentiality, that is, where the present is woven through the events that happen minute by minute, second by second, from of the decisions that are made or played in its own on-site deployment and which are chosen at any given time. But since this ability to opt is only the subject's protest, action decisions are often defined in the heat of the possibilities of viability that the options in question show for the subject in a given timespace.

In that sense, it is possible to affirm that history happens happening, that is, that history is formalized as history in its own becoming. This invoices the emergence of the possibility, of what is not yet but can be; and that is where the future is played. For these reasons, history occurs in being and therefore also in uncertainty, thus configuring a situation from which it is impossible to know in advance the forms and contents that will end up defining a specific order of reality.

That is why the socio-historical present -which here, from Bloch's hand we summarize as history-, is actually something unfinished, impossible to be determined as long as it occurs in motion; a constant movement, not necessarily transformative, and not necessarily progressive. The movement of history in the present is rather a movement that points to its configuration as present, as actuality; and as every configuration implies an order, a disposition, the configuration of the history of the present, understood as a configuration of the current social reality (Bloch, 2004), this is the order that the present acquires once the movement becomes more predictable and ordered, because the movement of reality does not cease as long as said social reality is always taking place, happening, happening through the intervention of the subjects in it, who are the ones who contribute with their action to configure it (Zemelman, 2009; De La Garza, 2001).

The matrix action that, in our opinion, makes possible the movement of social reality is communicative action, but not in Habermasian argumentative terms, but in praxis terms, of the very practice of communicating subjects. The communication, thus seen, becomes the

\footnotetext{
${ }^{3}$ For Bloch, the concept of history is closely related to the concept of utopia. This in turn impacts the ideology, understood by the author as the potential for the creation of historical surpluses that just constitute the culturally inheritable substrate of a possible future, where the human being constitutes the engine of history. Under this premise, the sense of the utopian of Bloch is articulated with the new through hope, understanding this as a guiding act of a historical-cognitive nature that constitutes the engine of the progressive activity of history. But it is a hope that is based on the possibility of being reached, because for Bloch the future is not what happens to man, but that where he goes, from where he continues to civilize himself. For more information we recommend consulting the author's work referred to in the bibliography of this work.
} 
mechanism that postulates this being and not being of history in the present, since the communication invoices that movement that makes possible the updating of the meanings, that is, the validity or not of the same in spaces of social interaction that are also always located, always historically constituted, just as the subjects that participate in it are historically constituted (Romeu, 2019c).

In that sense, the communicative processes constitute instances of production and updating of meanings or senses, which take place through the dynamics of these processes, making them temporary scenarios rather than realities given or determined a priori. In that sense, it is this situation that we use in the communicative processes that makes them visible as points of break in the configuration of social relations, understanding by them those that give the social reality a specific rhythm and order.

But the above implies giving the communicative processes a full importance in the understanding of the social (Romeu, 2019a; 2019b); understanding that it is possible to articulate from understanding the operational dynamics of these processes. In order to do so, it is necessary to reveal from what premises communication is treated here and how it is defined based on them.

The first thing to say about it is that communication, as we understand it in this work, is not a mechanism for sending and forwarding information, which inhibits its concretion as a mechanism of socialization, as assumed from the interactionist positions. The reason for this positioning must be found in our understanding of communicative phenomena as phenomena of expression, as behaviorally ${ }^{4}$ billed from the "say" (Romeu, 2018).

As all communication "says", postulating its dissident status based on the expressive acts of the communicating subject, communication cannot be, in principle, more than expression. This expression is constituted in an act of "saying", being that said "saying" is subjectively organized from meanings that the communicating subject makes available to other subjects, through its own expression ${ }^{5}$. Communication, thus understood, is the mechanism that allows an individual to project meanings to the public space, where the other subjects are, thereby billing a display of meanings that are inserted in the expressive resources ${ }^{6}$ that all communication needs to be such.

And it is that when communicating, the communicating subject mobilizes meanings because there is no communication that does not convey some kind of meaning through them. In this mobilization, however, these meanings are chosen, selected, but this does not take place in all cases in the same way because this choice is not always conscious and intentional, but it also plays the unconscious, and above all the affective, in turn involved in the subjectivity of the communicating subject (Romeu, 2019b).

Thus understood, communication - like any human act - results from what Maturana (2015) calls the emotional-rationality entanglement, which suggests not only body-mind

\footnotetext{
${ }^{4}$ We refer specifically to communication as behavior, that is, as a meaningful movement (Galarsi, al., 2011). For more information consult the text of the authors referred to in the bibliography of this work.

${ }^{5}$ We emphasize with emphasis the fact that saying acquires various supports and materialities, so that it is not possible to refer by saying only in linguistic terms. We say with words, but also with colors, smells, movement, temperature, distances, clothing, decoration, what we eat, what we do and what we feel, among many other examples. As you can see, the communication, as it is understood here, is embedded within a pan-communicative perspective that is, however, far from the pan-communicative postures of Palo Alto where the maximum is impossible not to communicate is billed from understanding every act human from its communicative value. We draw a different route to reach the same result: communication is a subjective expressive behavior, and as long as behavior is not optional, it communicates whether you want it or not. However, as we have seen, the expression does not need the validation of the other to be configured as a communicative act, but it suffices itself.

6 The expressive resources configure all those aspects that from the formal and conceptual point of view serve to communicate: words, meanings, colors, shapes, textures, frequency, intensity, etc.
} 
integration, but also the need to understand that our rational acts always have a affective imprint $^{7}$ - and vice versa -, which sometimes is even decisive in the construction of the meanings derived from experience.

The foregoing indicates that communicative acts carry with them an arsenal of meanings intermingling intellectual affections and knowledge that are displayed by the communicating subject based on multiple factors and motivations, thus configuring, through it, the material basis of the communicative processes, such which we have defined before. From these testaments, the communicative processes indicate the intrinsic movement of the communicative acts that, in situations of social interaction, enable their convergence.

And we talk about convergence and not about "sharing" (which is the way in which communication is mostly assumed) because the pooling suggests the misconception that when communication takes place a dialogue between consciences, oriented - for more signs towards understanding and rationality, and especially towards the other. This has allowed the construction of another of the great myths of communication: that it results from an intentional sharing with others, in the manner of an exchange of meanings, and not front of or by others, which is what is postulated here.

The above criteria synthesize, in essence, what the academic field of communication studies defines as communication. But this is a nonsense for several reasons, and the first of these points to the fact that consciousness, as content and continent of subjectivity (Damasio, 2000), is not transferable; Since the idea of "sharing" and dialogue between consciences is not transferable, it falls under its own weight, and the same fate is the idea of sharing and exchanging meanings with others because sharing is giving others something of their own, in this case meanings (which is the shareable in communication); but from there to suppose that what is shared is intentional (as if there were no unintended acts in the communication) and also to point out that this sharing is already an exchange, specifically an exchange of meanings, makes the act of sharing summarized in the way in which a communicating subject gives the other voluntarily meanings who in turn gives their meanings to him. The exchange is thus understood as a give and take, that is, as an act of transfer of meanings by both partners, which - clearly - is not what happens when we communicate.

When we communicate and do so in situations of social interaction, the expression of one subject serves as a stimulus for the expression of the other (Romeu, 2019b). This does not imply a sharing with others in the terms of the aforementioned exchange. In any case, sharing meanings with others constitutes the action of projecting meanings in the public space, and this projection - which is essentially subjective, as long as it is the subject, the individual, who makes it available to others. communicated meanings However, we must bear in mind that making the meanings publicly available is the only thing that guarantees that these meanings circulate in the public space, and can therefore be disputed.

As you can see, in no case does the projection of meanings give way to an exchange, much less to understanding and dialogue with others. We insist: communication constitutes an expressive commitment to or by others as long as it is a response or behavioral reaction of an

\footnotetext{
${ }^{7}$ Affections are atmospheres of meaning associated with an emotion, which we usually define through the concept of feeling. Affects are inevitably involved in the processes of meaning construction, since these processes take place from experience, and in experience, emotion comes from the sensory, so that when we feel we know what and what we feel. The latter is thanks to the presence of affections that allows us to assess emotion. For more information, the consultation of two works by Antonio Damasio El Descartes error is recommended. Emotion, reason and the human brain. Mexico City, Mexico: Editorial Paidós Booket and Damasio, 2015 and In Search of Spinoza. Neurobiology of emotion and feelings. Mexico City, Mexico: Editorial Paidós Booket, 2016. Additionally, the consultation of Andrew Ortony, Grerald Clore and Allan Collins is also recommended The cognitive structure of emotions. Madrid: 21st century, 1996.
} 
expressive type to the stimulus caused by its "saying," and it does not follow that communication is a sharing of meanings. Only in situations of social interaction, communication emerges its intersubjective, social status, from where - however - it cannot be affirmed that communication occurs with others, but rather with respect to them, about them.

Thus understood, the projection of meanings constitutes a subjective expressive act where meanings are expressed by a communicating subject. These meanings in turn are installed as a synthesis of the perceptual experience of the subjects both at the biographical, subjective, individual, and intersubjective, social and historical levels. In this way, the expression of a communicating subject bears the imprint of these experiences condensed in meanings, and even of those that are configured in the heat of the interaction experience where communication is taking place.

In that sense, the forms and contents of the expressions of the subjects that converge in situations of social interaction are redefined within them through the communicative interactions that take place under their protection. And it is that all communicative interaction is configured from the knotting that constitutes the sequentiality and juxtaposition of the expressions and meanings within a given interaction, giving as a possibility, following Hall (1980), three resulting options: that one of the communicating subjects accept the meanings of the other, reject them, or negotiate them. In both the first and third cases, one or both communicators, respectively, update their meanings generating conditions to reach an agreement in this regard; but in the second case, this is impossible, thus opening the possibility of conflict.

It is the latter that makes it possible to apply for communication as a scenario for the dispute over meanings; but since all communication is historically situated, while the communicating subjects are also so, it is presumably to notice that the meanings that are played or disputed in the communicative interaction are closely linked to the biographical and social identity of the communicating communicators, of so that from them the historical and subjective experience of them is also articulated that, in some way, also comes into dispute, together with the subjects' own identity, in the dispute over the meanings in question.

The foregoing, as you can see, describes the procedural logic of communication in situations of social interaction, from which it is presumable to notice the form and content that social relations are taking, as far as the communicative drift defined previously the positions that the subjects themselves occupy in the interaction result and are disputed. This is what will define the type, form and content of social relationships that, as Simmel (2014) pointed out, shape the processes of socialization ${ }^{8}$.

Thus defined, social relationships seem to be indebted to the always unfinished result of communicative interactions, which are conditioned by the types and operational modalities acquired by the communication or expression of the subjects in situation (Romeu, 2016). This in turn is billed from the type of expressive meanings ${ }^{9}$ and resources cognitively constructed and expressly mobilized, from the biographical and historical experience of the subjects, to be used in communicative interaction.

\footnotetext{
${ }^{8}$ In Simmel, the socialization processes are based on the type, form and content of social relations, which for the author are five: 1) of sociability, which creates relationships of horizontality, harmony and enjoyment, 2) of conflict where social relations are forged from a problem or tension, 3) of exchange where all forms of social relations where there is mutual benefit, 4) of subordination where an individual submits to another due to their weakness or inability and 5) of superordination where subordination is implied by compliance with certain institutional rules.

${ }^{9}$ As we have seen before, there are meanings of various types, understanding that these are constructed both from a sensitive, sensory point of view, where affective content is amplified, and those that are constructed from an intellectual position, via social learning, and where logical reasoning is involved in its construction.
} 
In that sense, it is clear that the meanings that are projected in the communicative interaction have the potential to be transformed in the heat of it, whether this takes place by conviction or coercion. In this way, communicative interaction - which is nothing more than the process where communicating subjects dispute the meanings they mobilize to communicate or express themselves, but above all to configure them as legitimate and hold the power of their reproduction in terms of representation of the world and the reality ${ }^{10}$ constitutes the arena of struggle where social relations are formed from this dispute ${ }^{11}$.

This postulates communication as the engine of social relations, thus accusing its role in the constitution of them and in the historical constitution of reality where they take place in the present, which evidences - from the intrinsic dynamism of their nature operational - that the historical reality of the present moves through the dynamics of the communicative processes, thus energizing the possibility of transformation of the meanings under which the reality itself is organized, based on practices, values, attitudes, knowledge and speeches.

This, as can be seen, makes the meanings the engine of human action and thought, which is related to what Zemelman proposed in his critical epistemology about parametric structures, as we will see below.

\section{The paradigm of critical epistemology: dialectic, history and social reality}

Zemelmanian parametric structures constitute the content of the intersubjective historical consciousness of a society, of a community in a given time-space (Zemelman, 2009, pp. 66-67). In that sense, the parametric structures house the intersubjective meanings that give form and content to an era, to a culture, thus impacting the configuration of a particular social reality, including in it, of course, the processes of identity construction Social.

It follows that these contents are updated based on the transformations that society is suffering through the human intervention that configures it, so its transformation can be postulated. However, the transformation of the parametric structures is always historical, gradual, unevenly and at different levels since it depends - at least indirectly - on the historical interconnection between the different representational systems of social groups through the aforementioned dispute- ; hence the importance of the dispute over the meanings via communication, because in it their transformation is played, thereby enabling potential and eventually the transformation of the social order.

This is what always happens in social reality, although its scope of transformation does not become visible, while such transformation is not always achieved. However, understanding its potential allows us to understand the processes of social transformation and the way in which communication processes participate in it. In that sense, the parametric structures - where the historically constructed social meanings nest - constitute the watershed of any possibility of transformation.

\footnotetext{
${ }^{10}$ We make a distinction between world and reality, by the hand of Luc Boltanski, a French pragmatist sociologist who points to the world as that which surrounds us but that we cannot describe linguistically, and to reality as the experienced and named world. For more information, it is recommended to consult the work of the author Enigmas and plots. An investigation into the investigations. Buenos Aires, Economic Culture Fund, 2016.

${ }^{11}$ This differs slightly from Jorge González's thesis on culture as an arena of struggle for the legitimacy of symbolic power. Although the author focuses on that in the culture such legitimacy is disputed, for us this place of dispute is objective, from the sociocultural instance, in the communicative processes, since the same dynamic of the communication (is given in scenarios sociocultural or not) implies the dispute in question. For a better understanding of this, we recommend consulting the text of Jorge González Cultural fronts: for a dialogic interaction of contemporary cultures. In Studies on contemporary cultures, Period II, VII (14), 2001, pp. 9-45.
} 
When social meanings manage to transform, this is because in the communicative processes where the dispute over meanings takes place, they are updated ${ }^{12}$; but for this to happen it is necessary to convince others of their obsolescence or impose them, thus creating a new parametric structure from which both reality and the world, including of course the social world, acquire meaning for much of the social subjects.

As you can see, the Zemelmanian parametric structures play a fundamental role in the processes of constitution of social reality. All social reality rests on them; from which it is agreed that social interactions - from where social relations are configured - are limited to these structures. However, the autonomy of the subject - which is an autonomy with respect to the historical processes of constitution of the subject in question (Zemelman, 2004) - gets instances for creativity and transformation. In this way, Zemelman's parametric structures cannot be compared to the social structures that rather constrain the subject, regulate and control him both in his action and in his thinking.

Thus understood, it is necessary to notice that the parametric structures configure the symbolic reference framework of a society, serving as a more or less homogeneous representational configuration of the world, reality, the other and the self. Therefore, from the above it is possible to affirm the configuration of social reality, as a historically possible reality, that is, as a reality that it has been possible to be constructed based on the historical options available for it (objective and subjective ${ }^{13}$ ), where, of course, circumstances, subjects and their actions are interwoven (De La Garza, 2001; 2009).

The foregoing allows us to reveal the dissimilar way in which the three aspects mentioned above are intertwined, as well as the uncertainty in which we are involved, as social analysts, said interweaving as a conjunctural. Although from certain circumstances it is possible to predict and even foresee the types, forms and contents that the subjects-actionscircumstances articulation could adopt, the truth is that these forecasts can accuse a false sense. Nothing - not even violence - can make such entanglements always occur in the same way; otherwise we could not tell the story of human civilization as the story of transformations that it is.

In that sense, as postulated from critical epistemology, social reality - which is the field of study of social scientists - is not and cannot be a static reality, but always on the move, and therefore potentially transformable. It is from here that the question about the ontology of social reality becomes imperative, obligatory. The inquiry about the ontological status of social reality thus appeals to determine what we observe when we observe reality.

Critical epistemology makes a remarkable effort to answer this question, separating two levels or dimensions of social reality: the dimension of the given, of the social structures historically objectified from practices, roles, positions and speeches, whether institutionalized or not, where reality is observed as something crystallized and / or determined beforehand, with no possibility of transformation as static; and the dimension of the giving, of the structure-structuring, as Quintar said $(2009$, p. 32), which is what characterizes the hustle of communicative interaction if it is understood as what causes the movement under that crystallized reality that It reveals itself to perception. Both dimensions take place

\footnotetext{
${ }^{12}$ A clear example of updating d meanings takes place through the gender issue, which is becoming a very sensitive issue in our times, realizing how the meanings about women have been changing - in this case for good - since some decades.

${ }^{13}$ As an example, serve the electoral triumph of the current president of Mexico, Andrés Manuel López Obrador, a triumph obtained after two previous attempts, so that the circumstances - both at the objective level or at the subjective level, or both must have changed. At one time, Evo Morales's resignation to the presidency of Bolivia is explained in the same way.
} 
simultaneously, under a kind of tension that Zemelman refers from the idea of structurestructuring as given-giving ${ }^{14}(1987 ; 1996 ; 2009)$.

But as we have seen before, crystallized reality is rather a mirage: an effect of our natural, non-scientific perception. When a subject observes reality, it is presented as what he sees, as that which is possible to perceive via his senses, so that what the subject naturally perceives is a given state of things, understanding what is given from a perspective space-time inscribed in the perception in question.

But what we see is not always what it is, and what it is is not always what we can see. In that sense, natural perception is dethroned as inoperative (and even harmful) as a mechanism of scientific apprehension of the world, because our human senses do not guarantee greater or better information to do science; and above all, they do not guarantee the apprehension of what is buzzing or moving under that apparent immovable order that social reality results when we observe it through the lenses of natural perception.

Paraphrasing Zemelman (1996; 2003; 2004; 2009), the scientific challenge is parapeted right there: in the change of lenses, because social science cannot operate on the basis of natural perception. In the author's opinion, the task of social science should be limited to the construction of possible worlds via the transformation of social reality, and for this it is necessary to inquire into the constitution of that reality, wondering how this constitution was possible and not another. That is why, in the question for reality, that the inquiry for its ontological status becomes relevant and pertinent.

As you can see, critical epistemology bills a materialistic definition of social reality because social reality is not understood as an entelechy or a narrative. Social reality is real, it exists, but not - or never - regardless of human actions. Just human intervention, as we have pointed out regarding the communicative processes, constitutes the engine of its constitution (Romeu, 2019a; 2019c); and it is thanks to the potential and eventual unpredictability of human actions that its movement is guaranteed and the impact of this movement in the future. So seen, it seems clear, that what from the critical epistemology social science must investigate is that which is moving in social reality, which is nothing other than the factors and relationships between them that play in its constitution.

As we said before, these factors are essentially three: the actors (subjects, with all their subjectivity in tow, where they echo, mixing with each other, the meanings: their own and the parametrics), the actions (acts and practices of the subjects, which here we have circumscribed to the communicative ones as the communication is explained as expressive behavior) and circumstances (which are externalities that impact on the subjects and their actions, favoring them or not in their own constitution).

It follows the need to understand social reality from a socio-historical perspective, that is, a perspective that allows to account for the historical constitution of the subjects (biographical and historical experiences and meanings associated with them) in order to understand its actions within a set of specific circumstances (externalities). This understanding clearly allows us to predict, prevent or procure transformative social action,

\footnotetext{
${ }^{14}$ What is given is the tension structure that is activated in social reality to the extent that it is constituted as such. The given represents the objective conditions of the social, especially in institutional terms, determined in discourses, structures, practices and roles fundamentally. What is happening, on the other hand, is the way in which these discourses, structures, practices and roles are configured in the heat of interaction. In that sense, its forms and contents are not given beforehand as long as they do not finish being configured and it is there at that unfinished juncture that it is possible to dispute the social meanings from the interaction itself. For more information, it is recommended to consult the works of Hugo Zemelman referred to in the bibliography of this work.
} 
which is something that concerns scientific ethics, built according to Zemelman $(1987 ; 2003 \mathrm{a}$; 2003b; 2011) and De La Garza (2001) in a political conception of the science.

This political conception of science starts from subverting the current scientific paradigm in social science that, according to Zemelman, can be called the appropriation discourse of science. From the author's opinion, the appropriation discourse of science coinciding with Maturana's (2015) concept of reality without parentheses ${ }^{15}$ - appeals to the scientific task from the natural perception that was previously discussed. In contrast, Zemelman (2004) postulates a discourse on the placement of science, from which the researcher or social analyst places himself before the world.

This position in front of the world demands its understanding, more than its description-explanation that is for Zemelman the way to study social reality from the appropriation discourse of science, and it is because from the natural perception that provides us with a vision of social reality as something given and determined beforehand, this reality can only be described; that is, only invoice descriptions of what is seen. In this way, it is inferred that the explanations on this description are based on the apparent reality, as long as that is what is seen, and not on what has made possible its constitution as historical reality.

This results in the problem of the scientific method, which for Zemelman, based on pre-Socratic thought, is the dialectic, as the only one capable of accounting for the movement of reality (Zemelman, 2003b; 2009). In this way, the dialectic makes it possible to think about social reality from scenarios not revealed beforehand (which is what is happening) in accordance with the unprecedented sense of social reality that the author defends, while the movement of matter - including here to social reality - it is essentially dialectical.

Dialectical thinking thus allows us to notice the intrinsic contradiction of all reality and its processes, with the understanding that the contradiction contains divergence. Thus seen, dialectical thinking allows us to investigate reality from a logic that allows the integration of macro and micro, theory and praxis, quantitative and qualitative as dichotomies inscribed in the natural and social phenomena themselves (Mandel, 1979).

As stated in the philosophical dictionary of Pelayo García Sierra (2018), the dialectic is not only present in thought, but in reality itself, which expresses the multilateral sense of relations, that is, their interconnections. This postulates, as you can see, a methodology that takes into account the understanding of reality from a complex and not isolated or fragmented position (which is what is done from the specialization statute of standard science), which is essential for its study every time, as we have said, in the constitution of social reality many aspects and factors intervene, all connected to each other at different levels and relational nodes (Mandel, 1986).

And is that dialectical thinking allows apprehend the real in all its complexity. In the case of social reality, dialectical thinking allows us to know the way in which the different factors or phenomena that affect reality interpenetrate to make it emerge as the unfinished, concrete totality that it is. The above makes the dialectical method the substitute, so to speak,

\footnotetext{
15 The concept of reality without parentheses refers, as opposed to the concept of reality with parentheses. In the first case Maturana points out that reality is a domain of reflections, that is, of propositions and statements about reality, while the observer is involved in the construction of said reality via the processes of cognition; In the second case, reality is assumed as a praxis domain. It is noteworthy that the difference between the domain of praxis and the domain of reflections postulates the difference between reality given to perception (domain of praxis) and reality built from perception (domain of reflections). By the way, the author points out the ingenuity of scientists when considering that they operate scientifically with a domain of praxis, when in fact they do so through a domain of perceptions. For more information, it is recommended to consult the author's work referred to in the bibliography of this work.
} 
of the hypothetical-deductive, of positivist roots, which despite the hermeneutical imprint in the social sciences still survives.

From this it follows that understanding the social reality from the paradigm of description-explanation nests in the standard task of science, generating explanations of reality that start from aprioristic explanations; that is: of explanations that have been forged from theories that have served to explain past realities. And considering that social reality is a reality in constant movement and potential transformation, it is presumable to assume that it is always unpublished.

An unprecedented reality, then, cannot be questioned scientifically if we put forward a theoretical scenario that speaks for it, since being unpublished, existing theories - in principle - may be inadequate to explain it. This implies that the standard use of the theory is inoperative and harmful to the scientific task in social research from the perspective of the discourse of placement of science, thus reducing the range of action of the hypotheticaldeductive that hinders - and sometimes prevents - its understanding.

Since social reality is, as has been said, a reality that must be understood historically, that is, structured and structured at the same time, this means revealing the factors that have formed or are being part of its constitution. That is why what the critical epistemology endorses in this regard consists in making a reconstructive use of the theory (De La Garza, 2001), for which it is necessary to underestimate its explanatory potential a priori and amplify the construction of categorical orders - that are not conceptual, since the concepts are inscribed in theoretical trajectories (Koselleck, 2004) and this would take us back to the hypothetical-deductive- to describe the phenomenon in its potentiality.

Here it is worth bringing up the Aristotelian distinction between act and power that results in the way in which the Estagirita could explain the movement, and the transformation and creativity associated with it. This distinction is useful since it allows you to accuse the difference between what is and what is not yet, but it may be; what expresses a correlation with the idea of situation and structure-structuring that we have referred to previously. Therefore, as you can see, this is closely related to the concept of social reality that is proposed from the critical epistemology since being this unprecedented reality and in constant movement, through human intervention must be understood as a potential being.

From Aristotelian metaphysics, being is not only taken in the sense of substance, quality and quantity, but there is also power and act in it. Actually, in the present, being is what it is at that moment and as such can be known in its properties; in potential, on the other hand, being becomes a possibility, that is, a possibility of transformation, of change, and its properties must be thought dialectically, that is, from the tension between being and nonbeing. Thus, the being in act represents the intrinsic materiality of the being, and the potential being is the non-being; and although it is a relative, never absolute non-being, the potentiality of being invites us to think about what it can become, even if it is not yet ${ }^{16}$.

But not every being in act can be a potential being ${ }^{17}$, basically because the potential of a being depends on the being itself, as contained in it. In the case at hand, which is social reality, it is revealed as being in act in its description and as being potentially in its understanding. In that sense, the scientific proposal of the critical epistemology, seeks to

\footnotetext{
16 The famous Aristotelian example around the seed is a good illustrative picture of the difference between being and nonbeing, or being in act and being in power, respectively. Aristotle refers to the seed as being in act, for the seed is seed and is nothing else; but that seed has the potential to become a plant, so that it is also a potential being. Thus, the seed is to be as a seed and not to be as a plant.

${ }^{17}$ A spoon for example, is nothing more than a spoon, because it has no potential to become something else by itself. A child, on the other hand, is a potential being as long as he can become an adult thanks to his own potential as a being.
} 
make its way from the knowledge of the potential of social reality and from there to build the construction of possible actions to build desirable realities; hence the ethical-political imprint of science, and in particular of social science, which is inspired by the postulates of critical epistemology; and hence also his insistence on redirecting the task of social science towards the understanding of said reality as the only way to know how to intervene from science through his collaboration in the design of public policies.

Thus, as we have seen, the Aristotelian concept of power allows us to talk about the future, about what it is not yet, and how social reality - in terms of novelty and constant change from which we have described it - is always an expression projective of the future, it is impossible to know in advance why it has been constituted as it has done. Recall: for natural perception, social reality is revealed as it is and in that sense it is perceived as a fact, as something static and given, although fragmented, dissociated from the integrality of its essence; but scientific apprehension travels through other paths and makes an important distinction with respect to the way of building knowledge; Therefore, it is necessary to transform the ways in which we approach epistemically and methodologically to social reality.

Taking this into account, and assuming that from the epistemological point of view we have already reflected on it, it remains to focus on the methodological part, which will help explain how communication research sets up the embarkation point of all social research.

\section{Communication research and its role within social research}

To begin this section, it must be said that the academic field of communication studies is registered within the academic field of social sciences. But as Fuentes Navarro (2011) points out, as well as Fuentes and Sánchez (1989), that of communication is subject to triple marginalization: that which is billed within the social sciences where communication research does not commonly appear; the one that takes place between "hard" and social sciences that benefits the former; and the one that finally is postulated from the public policies in the matter of science, where social science, before the technological avalanche is virtually displaced.

However, being critical, we must admit that this triple marginalization - not accepted or acceptable in any case and circumstance - would be related to what has been holding paragraphs above. This is: it is related to the way in which social reality and the communication inscribed in it are conceived, which impacts research and the results it produces in terms of impact on the resolution of social problems; Although we are aware that not only these factors are involved, but also others such as research policies in academic centers, infrastructure, financing, etc. (Rivas, 2003).

With regard to the above, a brief look at the panorama of social research in Mexico, and particularly communication research reveals that just over $10 \%$ of high-level researchers focus on the area of social, where sociologists, economists and Political scientists occupy the first places, being that the psychologists reach the eighth place (Rivas, 2003, p. 52). In addition to the alarm figures, this may suggest - as the author does - that the social sciences are poor in generating human resources for social research, which worsens if the focus is focused on private schools ( Rivas, 2003, p. 53), and the same happens if we redirect the eye to the state panorama (Rivas, 2003, p. 54; COMECSO, 2015).

In that sense, we can say that social research in Mexico has no promising results; and if we focus on communication research less. A study by Moyano (2018) in this regard reveals a clear decrease in media research and the consolidation of other fields of study under this displacement. Coincides with this Fuentes Navarro (2011, p. 218) when he points out that communication research in Mexico becomes more rigorous in theoretical-methodological 
terms, operating in turn from applied research in a considerable effort to produce data ${ }^{18}$ and insert thus in a more solid scientific dynamic (Fuentes Navarro, 1998).

However, Moyano's study also reveals that although in recent decades the objects of study have diversified in communication research, the dominant theoretical paradigms have not varied essentially, which in the author's words assumes the presence of a limited theoretical concentration that, however, results in mostly descriptive research, not only in Mexico but throughout Latin America (Moyano, 2018, p. 313). Something similar have been raised by Fuentes (2009) and Vidales (2011), which is related to the weight of the appropriation discourse in science that tends to explain reality from the logic descriptionexplanation, more than to understand it.

In that sense, even though a greater and more diverse reflective development has been proven around the theoretical-methodological foundation of the scientific production of the communication field at least in Latin America, this is insufficient in terms of research results, especially since, as Moyano (2018) points out, the diversity of theoreticalmethodological approaches does not echo the level of epistemological discussion. This, in our opinion, is related to the absence of a properly communicative analysis dimension, as denounced by Moyano (2018), Chaffee (2009) and Sanders (1989), which in turn has its origin in the postponed debate around the ontology of communication as a phenomenon.

Vidales (2016, p. 66, citing Zelizer, 2008) states in this regard that the naturalization of disciplinary knowledge in the field of communication studies has hindered the conceptual construction of communication, making current the criticisms of which it has been subject the field internationally by various authors over the years. From Berelson (1959) to Peters (1986), questions about intellectual poverty in communication research make common ground with the criticisms of Fuentes Navarro (2009) about what he calls "superficial immediacy" in studies of communication.

But we can also cite Donsbach's (2006) harsh criticism of epistemological erosion regarding what he considers the loss of normative principles in communication research; or the confusion about communication theories such as that denounced by Anderson (1996), as well as the lack of rigor in the use of concepts in communication research processes that Chaffee $(1991 ; 2009)$ points out.

Sanders (1989), meanwhile denounces the usurpation of research programs and agendas outside the field of communication, and Craig (1999) refers to the "routes of incoherence" to characterize the very history of the field of communication. From the same line, Shepherd, St. John and Striphas (2006) denounce what they consider a "theoretical pluralism" within the field, criticism that is endorsed by Vidales (2011, 2012 and 2013) when he refers to the phenomenon of "theoretical relativism "In communication research.

From another rope, factors such as those denounced by Meyer and Fernández, (2012, p. 33) weigh around the lack of self-criticism within the field. The most immediate result of this has been felt in the negative impact that this has had on the construction of its disciplinary identity. In this regard, Swanson (1993, p. 411) has indicated that the interdisciplinarity of the field of communication is sustained from the historical and political tradition rather than from an intellectual one, preventing the construction of a common

\footnotetext{
18 The fact that the production of data from scientific research is inserted in an epistemic-methodological conception of reality as something consummated, typical of positivism and hypothetical-deductive, must not be dismissed. Data comes in fact. And produce data as evidence of facts, sadly, sadly, that conception. Zemelman (s / f-b) proposes to understand the data as indicatum.
} 
disciplinary perspective, which in turn, as Peters (1986) has indicated, the "immaturity" of the field of communication.

The above adds to the harsh criticism made by Follari (2000) regarding the contradiction that exists in the self-proclamation of an interdisciplinary statute of the field of communication without first having developed a serious and consistent reflection on the scientific status in terms of its own discipline. In that sense, it is possible to affirm that the problem of the undefined identity of the field is of a structural type, constitutive of the field itself, and it undoubtedly has to do with a deeper question.

With regard to the above, Sanders (1989, pp. 223-224) states that although there is a multidisciplinary interest in communication, for sociological reasons rather than intellectual, this has prevented the integration of results in a common body, favoring the thematic, theoretical and methodological dispersion, and hindering the task of generalization; hence the lack of the field in terms of disciplinary reference.

Unfortunately, in spite of the critical voices that we have mentioned, the absence of this debate within the field avoids a discussion about the scientific method in general and in particular - as we already said - in what refers to the conceptual definition of the communication. This has enabled the emergence of a conceptual, epistemic and methodological improvement that, coupled with the inter and transdisciplinary logic inherited from the social sciences, scientifically weakens the academic field of communication studies, impacting in turn on an incorrect conception of phenomena of the human and social reality that he studies, and imposing from it an unreal sense of reality that hinders and prevents the emergence of a dynamic conception of it, as proposed from the critical epistemology.

It is from this dynamic conception of social reality that it is possible to make visible its historical-procedural dimension, always in constant configuration and reconfiguration, precisely thanks to the role of social subjects in the organization, development, consolidation, reproduction and / or transformation of the social reality they inhabit and where they operate, and to which of course they contribute to create.

As already mentioned, the communicative processes that occur in the present of the social reality allow the subjects and their actions to be articulated within a set of determined circumstances, thus offering an overview of how communication connects with the most structures. deep experience and human action, through which the structuring of the meaning or meanings of each subject and group of social subjects in front of it inevitably occurs.

Therefore, not paying attention to the role of these processes in the historical construction of meanings negatively impacts the way in which we can understand social reality. From the conceptual proposal on the communication that has been exposed in the first section, we consider that the above can be remedied for several reasons.

First: because understanding the communicative processes and phenomena as an engine for the emergence of social relations, postulates communication as a mechanism that affects its configuration, thereby making communication visible as a constitutive dimension of social reality. Second: the expression is postulated as a unit of analysis in the study of communicative phenomena, which implies that the participation of communication in the constitution of social reality is centered on the projection of meanings. Third: it is the dynamics of projection of meanings, always in constant motion, that enables the movement of social interaction via communicative interaction, that is, through the sequential and / or juxtaposed projection of meanings in the public scene., which is where these are socially disputed. Fourth: on the circulation and appropriation of these meanings, the configuration of the social reality of the present is made dependent on the given tension, from which it follows that the type, form and content of the meanings that come out "winners" in said Dispute will 
be objectified in a specific type, form and content of social relationship, thus reverting to meanings via communication from this new installed social relationship.

The above, as you can see, makes communication an irreplaceable dimension in the analysis of the social, which methodologically can be operated through its analysis. This analysis comprises three levels: the first, which organizes the dimension of possibility of an expression, thus focusing on its own emergence. At this first level, the criteria to be taken into account would be focused on the communicating subject and their cognitive resources to build information about the environment. Since communication operates with information, which we have previously called meanings, based on biosemiotic ${ }^{19}$ and neurocognitive theses ${ }^{20}$ that allow us to apply for information not as a given magnitude without human intervention, but as one involved in the subjective subjective processes themselves and intersubjectives. In that sense, this level of analysis is billed primarily from phenomenology, because in all of this - as we have already explained - experience, as an instance for the construction of senses, is implied.

A second level of analysis focuses on studying everything related to expression. In that sense, this level investigates the discourse or statement resulting from the projection of meanings, especially those related to expressive resources, that is, with the form and content of the expression, what happens through the selection of meanings used to "say." From this perspective, the second level of analysis of communicative phenomena focuses on the studies of discourse and rhetoric ${ }^{21}$.

On a third level, the level of the motivations and interests of the communicating subject at the time of expressing (se), seeks to understand what has led the communicating subject to communicate what he communicates, that is, to what his expression has responded (when, how much, how, where, why and for what it communicates). This, as you can see, has a more pragmatic vocation and is directly related to the intentionality and context situation of the communication, thus immerse itself with the other two to offer more finished results.

So far, as we have seen, these three levels of analysis that we have exposed allow us to understand how an expression is configured and under what circumstances it takes place, which responds to the criticisms made to the field in regard to the definition of Object of

${ }^{19}$ Biosemiotics is a branch of theoretical biology that postulates semiotic or interpretation processes as natural processes. Cognitive activity is essential in the processes of survival and adaptation of individuals and species. This is because the interpretation to which this activity appeals constitutes the way in which living organisms build a meaningful relationship in the world around them and where they are vitally inserted. Therefore, a correct interpretation of the signs they perceive in the environment guarantees - up to a certain point - the adaptation and survival of the organism in question. In that sense, from biosemiotics it is assumed that through the interpretation that all living beings make - each one at their level and with their own scope - for the purpose of adaptation and survival to the environment in which their life cycle develops . For a better understanding of these postulates it is recommended to consult the work of Jesper Hoffmeyer, Biosemiotics. An examination into the signs of life and the life of signs, 2008 and Biosemiotics: Towards a new synthesis in Biology, 1997.

${ }^{20}$ Cognitive neurosciences constitute a body of theoretical reflections based on scientific experiments that are articulated around cognitive psychology and neurobiology. Therefore, study the biological foundations of cognition, focusing specifically on the study of neural substrates and their behavioral manifestation. For more information, the consultation of diverse works is recommended. First, Antonio Damasio's referrals (see bibliography and note 6), but it is also necessary to refer to the texts of Ezequiel Di Paolo Extended life. Topoi, 9-21, 2009 and Enactivism and the naturalization of the mind. In New Cognitive Science. Towards an integral theory of the mind. Madrid: Plaza and Valdés, 2015. In the same way it is recommended to consult the work of Francisco Varela, in his texts Autopiesis and a biology of intentionality. In B. McMullin and N. Murphy (eds.) Autopiesis and Perception. Proceeding of a Workshop held in Dublin City University, August 25 and 26, 1992, pp. 1-14; and the work of Andreas Weber and Francisco Varela, Life after Kant: Natural Purposes and the Autopoietic Foundations of Biological Individuality. In Phenomenology and the Cognitive Sciences 1, 2002, pp. 97-125.

${ }^{21}$ Between the first and the second level, the communicative interactions that take place in situations of social interaction must be able to be explained in turn from the social theory; and depending on the phenomenon in question, the approaches can be macro and / or microsociological. The latter, however, because of its link with the phenomenological and psychological, is especially relevant to complement the analysis of the pragmatic level of analysis. 
study of communication. For us, this object of study is billed from the expressive use of the information that the subjects build via their vital and historical experience in the course of their life cycle, and that is what allows the idea of communication to be positioned here. we maintain, namely: its main participation in the processes of constitution of social reality.

However, for the purposes we pursue here, to the three levels of analysis above, it is necessary to add a fourth level: that of the effects of communication. This, because investigating them makes it possible to understand the direction in which the meanings in an interaction travel from one subject to another, which is important since, as we have said, the crux of the thesis that we hold here in favor of the constitutive role that they have the communicative phenomena in the configuration of social relations and in the historical constitution that through it allows the emergence of social reality, consists in making the meanings the hinge that articulates subjects, actions and circumstances. In fact, as the meanings mediate between the subjects and their actions, and as these meanings are constructed in specific socio-historical conditions, it is presumably to affirm that the actions of the social subjects are configured from this mediating role of the meanings within a specific social situation, thus contributing to its concretion.

In other words: this fourth level of analysis allows us to understand the result of the dispute over social meanings, which is what is involved in the type, form and content of the social relationships that are built under its protection. In that sense, the fourth level of analysis that has been proposed here puts the focus on the consequences of communication, that is, on the results of the communicative interaction based on the correlation of forces around possession and legitimization of the resulting meanings.

As you can see, the methodological proposal that we have outlined here contributes to the inter and transdisciplinary exercise of science that is postulated from the critical epistemology. That is why here we have tried to articulate, in the first instance, communication with sociology; but as we have seen, it is also necessary to use phenomenology, rhetoric and pragmatics. To this is added the fact that the definition of communication to which we have pointed out constitutes in itself a transdisciplinary definition, since it sinks in a preponderant way in evolutionary biology, neurobiology, cognitive neurosciences, biosemiotics and phenomenology. (Romeu, 2018; 2019c).

All these areas of study are unpublished for the field of communication studies; Hence, from them it has been possible to pay for a definition of the communicative phenomenon as subjective expressive behavior, from which it has been possible to invoice the thesis that we have been supporting in relation to the role of communicative phenomena in the constitution of the socio reality -historical present.

In that sense, this thesis allows, in turn, to break with the theoretical-methodological homogeneity that characterizes the field of studies on communication today, inasmuch as it is currently limited to the theories of the culturalist and critical perspective of sociology, thus enabling the expansion of the theoretical and methodological scope of communication research, since the proposed scenarios can not be noticed anything that a priori privileges existing theoretical bodies. Rather, what we have tried to highlight here is the theoretical versatility that our proposal necessarily points to.

Thus, through the above, communication research can move from description to the understanding of social phenomena, since the methodological model that we have exposed activates an integral conception of communicative phenomena that contributes to understanding the way in which they are constituted and instituted as such, thus making visible their conditions of appearance and deployment, which is what we have indicated since the critical epistemology, allows us to understand what has impacted and how in the 
configuration of a given social reality constituting it in what it is. This is the question of the social reality which, from this epistemological paradigm, is given full importance in the scientific task of social science.

This, as you can see, transcends the disciplinary vision without diluting it, to the extent that it postulates an inter and / or transdisciplinary scenario in social research, which understands it as an unavoidable imperative, given the state of current knowledge in the field. And with regard to the field of communication studies, the above implies its openness to the study of communicative phenomena within social phenomena, which appeals to an investigation focused on social problems and not on topics and / or topics which is what makes communication research a fragmented one.

To conclude, we must say that although social reality is a reality always in motion, we have two options to study it: either we take it as a fact that has already happened, thus investigating what made its constitution possible as reality; or we study the situation in which this social reality is taking place. In both cases, the given tension given by Zemelman is present: in the first case, as an accomplished tension, and in the second as what is taking place. The difference between one and the other presents different methodological challenges, since approaching to study a consummate or consuming social reality poses a different way of approaching the meanings (discussion that we have to avoid due to space issues), thus impacting on their understanding, although the The flexibility of the proposed analysis model serves as a guide in both cases.

\section{Conclusions}

As it is possible to sustain, from all of the above, the focus of communication research focuses on understanding it as a process, and specifically as a process that takes place within historicity regimes that from Hartog's opinion ( 2007) is what shapes a perspective of the present that allows the researcher to interrogate the moment in which present, past and future are articulated making the experiences of time intelligible, thus establishing a parallelism with the Zemelmanian parametric structures that in this work we have synthesized as a framework of symbolic references.

This makes visible the tension between what Hartog calls the field of experience (past) and the horizon of waiting (future), which is what makes us think of the present as an instance of articulation between past and future, or either, between what is given and what is to come, billing simultaneously in that structured reality and structuring itself at the same time as it is the social reality. In this way, social actions - always located in the present of their occurrence - constitute an instance of meeting between past experiences and expectations towards the future.

That is where, in that confluence, that the dispute over social meanings acquires meaning, because what is disputed in itself is an order of representation of the world and the reality that is configured from the horizon of Hartog's expectation in the expectations of Sense projected into the future. In that sense, it is that the dispute for the meanings is defined - even if it is an immediate or near future - as a dispute for the future; hence its relevance.

This is where communication is affirmed as the mechanism that configures through process communication the process dynamics in the construction and negotiation of the meanings inscribed therein, since through this dispute social relations are played. Therefore, as social reality is always a reality being, and in this being the communicative processes are necessarily involved, it is possible to infer then that the understanding of the social goes through the analysis of these processes, in the understanding that they contribute to understand the way in which social relations develop and take place, which are configured in the heat of communicative interactions. 
The foregoing postulates communication as an action, and specifically the communication that takes place in situations of social interaction as a social action in question. The social action, thus understood, occurs through the drift of the communicative processes that occur between the different social subjects, so that the communicative experience of these subjects, given always in situation, already invoices an experience of social action, since such action is acted upon and through that action it is said.

Thus understood, understanding communication from the epistemological and methodological criteria that we have referred to, has an impact on its investigation. This impact happens, as we have seen, to understand its role in the constitution of social processes, and this, by the hand of the critical epistemology of Zemelman, allows us to assume communication as a typical phenomenon taking place. Investigating social phenomena from the dialectical and dynamic status of this definition of communication supports a scientific task aimed at discovery, that is, the search for those conditions for the constitution of a reality.

This distances itself from standard research that seeks to verify existing theories through the production of data, since the scientific use of the discovery abdicates the standard use of theories; otherwise the logic of the discovery would end up being unfeasible. There is no discovery, as we have said before, if the theory speaks a priori for reality. The discovery is billed from uncertainty, the conjuncture and surprise, and in that sense the path of theoretical verification is also inoperative.

It is necessary to think that if the investigation of the communication continues drawing a route that appeals to the verification of the theory, it will be impossible that it can generate scientific knowledge to understand the social reality, and eventually intervene, which is - in accordance with the position of the Critical epistemology - what would really impact social science in the resolution of social phenomena.

In these times in which the phenomena and communicative processes have become visible as fundamental in the understanding of contemporary societies, the relevance of the thesis that we have sustained regarding the role of communication in the configuration of social relations and consequently seems evident in the configuration of the socio-historical order from which these relations are objectified, thus objectifying it in turn.

Thus, although this proposal certainly postulates a change of course not only in the way in which communication research is currently done, but also in the way of conceiving of communication as a field and object of study, we nevertheless consider that its commitment It contributes to providing the field of studies on the communication of a scientific research proposal that precisely enables its foundational place within the social sciences.

\section{References}

[1] ARISTÓTELES: De la potencia y de la privación. Libro IX. Text on line in http://www.filosofia.org/cla/ari/azc10251.htm

[2] ANDERSON, J. A.: Communication eory. Epistemological foundations. New York: Guilford Press, 1996.

[3] BERELSON, B: The state of Communication Research. Public Opinion Quarterly, (23), 1-6, 1959.

[4] BLOCH, E: El principio esperanza. Madrid: Trotta, 2004.

[5] CHAFFEE, S. H: Communication Concepts 1: Explication. Newbury Park, CA: Sage, 1991.

[6] CHAFFEE, S. H: Thinking about theory. En Stacks, D. W. \& Salwen, M. B. (Eds.), An integrated approach to communication theory and research: (pp. 13-29). New 
York: Routledge, 2009.

[7] COMECSO: Informe sobre las Ciencias Sociales en México, 2015. Text in line, in http://foroconsultivo.org.mx/libros editados/Ciencias sociales mexico COMECSO2016.pdf

[8] CRAIG, R: Communication Theory as a Field. Communication Theory, 9(2), 116-161, 1999.

[9] DAMASIO, A: Sentir lo que sucede. Cuerpo y emoción en la fábrica de la consciencia. Santiago de Chile: Editorial Andrés Bello, 2000.

[10] DE LA GARZA, E: Subjetividad, cultura y estructura. Iztapalapa 50, enero-junio, 83-104, 2001.

[11] DE LA GARZA, E: El uso crítico dela teoría de Hugo Zemelman: una mirada 20 años después. Prólogo a la Segunda Edición de El uso crítico de la teoría. En torno a las funciones analíticas de la totalidad, 25-28. México: Instituto Politécnico Nacional, 2009.

[12] DONSBACH, W: The Identity of Communication Research. Journal of Communication, 56(3), 437-448, 2006.

[13] FOLLARI, R. Comunicología latinoamericana. Disciplina a la búsqueda de su objeto. Fundamentos en Humanidades, 1(1), enero-junio. Universidad de San Luis, San Luis, Argentina, 2000.

[14] FUENTES, R.; SÁNCHEZ, E. Algunas condiciones para la investigación científica de la comunicación en México. In Huellas, Cuadernos de divulgación académica, 117. México: ITESO, Guadalajara, 1989.

[15] FUENTES, R: Condiciones institucionales para la práctica de la investigación académica de la comunicación: la persistencia de la triple marginalidad en México. In E. Sánchez Ruiz (coord.), Qué pasa con el estudio de los medios. Diálogo con las ciencias sociales en Iberoamérica, 15-55. Zamora, España: Comunicación Social, 2011.

[16] GALARSI, M. F.; MEDINA, A.; LEDEZMA, C.; ZANIN, L: Comportamiento, historia y evolución. En Fundamentos en Humanidades, Universidad Nacional de San Luis - Argentina Año XII, II, 24, 89-102, 2011. Text on line, in: http://fundamentos.unsl.edu.ar/pdf/articulo-24-89.pdf

[17] GARCÍA, P: Diccionario filosófico, 2018. Text on line, in http://www.filosofia.org/filomat/

[18] GIMÉNEZ, G: Estudios sobre las culturas y las identidades sociales. México: CONACULTA-ITESO, 2007.

[19] HALL, S: Codificar y decodificar. In Culture, Media y Language. London: Hustchinton, 129-139, 1980.

[20] HARTOG, F: Regímenes de historicidad. Presentismo y experiencias del tiempo. México: Universidad Iberoamericana, 2007.

[21] KOSELLECK, R: Historia de los conceptos y conceptos de historia. Ayer, 53 (1), 27 45, 2004.

[22] MANDEL, E: El capitalismo tardío. México: Era, 1979.

[23] MANDEL, E: Las ondas largas del desarrollo capitalista. La interpretación marxista. Madrid: Siglo XXI, 1986.

[24] MATURANA, H: La objetividad. Un argumento para obligar. Buenos Aires: Granica, 2015.

[25] MEYER, J. A.; FERNÁNDEZ, M. B: Revistas académicas de comunicación en México: evaluación inicial de su contribución disciplinaria. In Elegir dónde publicar: 
(pp. 25-34). España: Sociedad Latina de Comunicación Socia, 2012.

[26] MOYANO, R: La investigación académica de la comunicación desde la perspectiva de los sistemas complejos. In Chasqui, Revista latinoamericana de comunicación, 136, diciembre 2017-marzo 2018, 299-321, 2018.

[27] PETERS J. D: Institutional Sources of Intellectual Poverty in Communication Research. Communication Research, 13 (4), 527-559, 1986.

[28] QUINTAR, E: ¿Qué sujeto se quiere formar? Prólogo a la Segunda Edición de El uso crítico de la teoría. En torno a las funciones analíticas de la totalidad, 29-32. México: Instituto Politécnico Nacional, 2009.

[29] RIVAS, L: Panorama de la investigación en ciencias sociales en México. Análisis crítico y cuantitativo del Sistema Nacional de Investigadores. In Revista del Centro de Investigación, 5, 20, enero-julio, 43-55, 2003.

[30] ROMEU, V: Pensando a la comunicación y al fenómeno comunicativo. In Anuario XXIII CONECICC, 17-55, 2016.

[31] ROMEU, V: El fenómeno comunicativo. México: Editora Nómada, 2018.

[32] ROMEU, V: Interacción comunicativa, relaciones sociales y discursividad social: reflexiones desde la articulación entre comunicación y lenguaje. Question, 1 (61), enero-marzo, 2019a.

[33] ROMEU, V: La comunicación como expresión. Una apuesta biofenomenológica. Revista Iberoamericana de Comunicación, 36, 45-80, $2019 \mathrm{~b}$.

[34] ROMEU, V: La comunicación viva. Reflexiones desde y para las ciencias sociales. El Portal de la Comunicación, 2019c. Text on line, in https://ddd.uab.cat/record/216458? 1 =ca

[35] SANDERS, R. E: The Breadth of Communication Research and the Parameters of Communication Theory. En King, S. (Ed.), Human Communication as a Field of Study: (pp. 221-231). New York: State University of New York Press, 1989.

[36] SHEPERD, G., ST. JOHN, J. \& STRIPHAS, T: Introduction: taking a stand on eory. En Communication as... Perspectives on theory (pp xi-xix). Ousand Oaks: Sage, 2006.

[37] SIMMEL, G: Sociología: Estudios sobre las formas de socialización. México: FCE, 2014.

[38] SWANSON D. L: Fragmentation, the Field, and the Future. Journal of Communication, 43(4), 163-173, 1993. sLE.

[39] VARELA, F: Conocer. Barcelona: Gedisa, 2005.

[40] VIDALES, C: El relativismo teórico en comunicación. Entre la comunicación como principio explicativo y la comunicación como disciplina práctica. Comunicación y Sociedad, Nueva Época, 16, 11-45, Universidad de Guadalajara, 2011.

[41] VIDALES, C: De la información y la cognición a la comunicación y el sentido: la naturaleza de la integración cibersemiótica. En Gutiérrez, C. (Coord.) XIX Anuario de Investigación de la Comunicación, CONEICC: (pp. 37-58). México: CONEICC, 2012.

[42] VIDALES, C: Comunicación, semiosis y sentido. El relativismo teórico en la investigación de la comunicación. Salamanca, España: Comunicación Social, 2013.

[43] VIDALES, C: Una mirada epistemológica al estudio de la comunicación. En Rebeca Padilla y Miriam Herrera-Aguilar (coords.) Historia y aportes sociales de la investigación de la comunicación en México. Acuerdos y discusiones sobre su núcleo disciplinario: (pp. 46-70). México: facultad de Ciencias políticas y sociales de la Universidad Autónoma de Querétaro / AMIC, 2016.

[44] ZELIZER, B: When disciplines engage. En Zelizer, B. (Ed.), Explorations in 
Communication and History: (pp. 1-12). London and New York: Routledge, 2008.

[45] ZEMELMAN, H: Pensar teórico y pensar epistémico: los retos de las ciencias sociales latinoamericanas. México: IPECAL, s/f-a.

[46] ZEMELMAN, H: El futuro como ciencia y utopía. (conferencia en el Centro de Investigaciones Interdisciplinarias de la UNAM), s/f-b. https://www.youtube.com/watch?v=8hKbd0VUCLk

[47] ZEMELMAN, H: La totalidad como perspectiva de descubrimiento. Revista Mexicana de Sociología, XLIX, 1, enero-marzo, 53-86. México: UNAM, 1987.

[48] ZEMELMAN, H: Conocimiento y sujetos sociales. Contribución al estudio del presente. México: COLMEX, 1997.

[49] ZEMELMAN, H: Los horizontes de la razón I. Dialéctica y apropiación del presente. España: Anthropos, 2003a.

[50] ZEMELMAN, H: Los horizontes de la razón II. Historia y necesidad de utopía. España: Anthropos, 2003b.

[51] ZEMELMAN, H: Historia y autonomía en el sujeto. VIII Encuentro regional de investigación, 2004. In https://www.youtube.com/watch?v=tIrKmPZC5j4

[52] ZEMELMAN, H: El uso crítico de la teoría. En torno a las funciones analíticas de la totalidad. México: Instituto Politécnico Nacional, 2009.

[53] ZEMELMAN, H: Los horizontes de la razón III. El orden del movimiento. España: Anthropos, 2011. 